\title{
Synthesis of Di -Acyl Triazene - N - Oxide
}

\author{
M. O. Edema*. and S. I. Onyeka \\ Chemistry Department, University of Benin, Benin City Nigeria. \\ E-mail:oliremay@yahoo.com
}

\begin{abstract}
Diacyl triazene - $N$-oxides were synthesized by reaction of $p$-nitroso, $N, N$-dimethyl aniline with some acyl hydrazines. The product yield varied from $56 \%-80.8 \%$. The conditions for optimum yields and spectral characteristics of the products are reported.
\end{abstract}

\section{INTRODUCTION}

Triazene $-\mathrm{N}$ - oxides reported so far are mainly of the type $\mathrm{R}^{1}-\mathrm{N}=\mathrm{NH}-\mathrm{NHR}^{11}$ where $\mathrm{R}^{1}$ and $\mathrm{R}^{11}$ are alkyl or aryl groups $^{1,2}$. Hoesch and Koppel $^{3}$ however reported the synthesis of unsymmetrical disubstituted triazene $-\mathrm{N}$ - oxide from $\mathrm{N}$ aminophthalimide and nitrosobenzene via the formation of the phthalimidonitrene. Triazenes $-\mathrm{N}-$ oxides have been shown to form brightly coloured metal complexes and may therefore be used as complexing agents in metal ion analysis ${ }^{4}$. Some have also been reported to show antiinflammatory activity ${ }^{5}$.

This work is aimed at preparing diacyl triazene $-\mathrm{N}$ - oxides from $\mathrm{p}$ - nitroso$\mathrm{N}, \mathrm{N}$-dimethylaniline with benzoyl hydrazine and six other substituted benzoyl hydrazines. The conditions for optimum yield were also determined.

\section{EXPERIMENTALS}

The p-nitroso-N,N-dimethylaniline (pNDA) was prepared by the reaction of N,N-dimethyl aniline and nitrous acid ${ }^{6}$ while the acyl hydrazines were prepared by the method reported by Chaco and Liver $^{7}$. The acyl hydrazines prepared were:
$1 \quad$ Benzoyl hydrazine

2 o-methylbenzoyl hydrazine

3 m-methylbenzoyl hydrazine

4 p-chlorobenzoyl hydrazine

5 o-chlorobenzoyl hydrazine

6 p-aminobenzoyl hydrazine

7 isonocotinic acid hydrazide

Preparation of the Triazene $-\mathbf{N}$ - oxide

Two methods were used for the synthesis.

\section{Method 1 Direct Reaction}

$0.015 \mathrm{~mol}$ of the p-NDA was mixed with $2 \mathrm{~cm}^{3}$ of concentrated $\mathrm{HCl}$ and dissolved in $80 \mathrm{~cm}^{3}$ of distilled water. $0.01 \mathrm{~mol}$ of the acyl hydrazine was dissolved in minimal distilled water and both solutions were kept in a preheated water bath at $30-50^{\circ} \mathrm{C}$ to equilibrate. Both solutions were then mixed and the $\mathrm{pH}$ adjusted with sodium ethanoate to between 2 and 5 and left for 6hours. The product was filtered, washed with cold distilled water, air-dried and weighed. The precipitate formed was purified by dissolving in tetrahydrofuran, filtered and re-precipitated with petroleum ether. 


\section{Method II Reaction via Nitrene}

Lead tetraacetate was prepared by methods described by Vogel $^{6}$. $0.01 \mathrm{~mol}$ of the lead tetraacetate was dissolved in acetic acid and 0.10 mol of the acyl hydrazine was put into the acetic acid mixture, stirred and then poured into $130 \mathrm{~cm}^{3}$ of water. 0.15 mol of the p-NDA was mixed with $3.5 \mathrm{~cm}^{3}$ of acetic acid and dissolved in distilled water. Both solutions were regulated to varing $\mathrm{pH}$ of $4-5$ using sodium ethanoate and mixed. The mixture was kept in a regulated water bath for 6hours and then the product was filtered out, air dried and weighed.

The product was washed with cold distilled water and air-dried, then purified by dissolving in tetrahydrofuran, filtered and re-precipitated with petroleum ether.

The melting point, UV and IR spectrum of the purified products were determined.

\section{RESULTS AND DISCUSSION}

The reaction scheme is

Method I
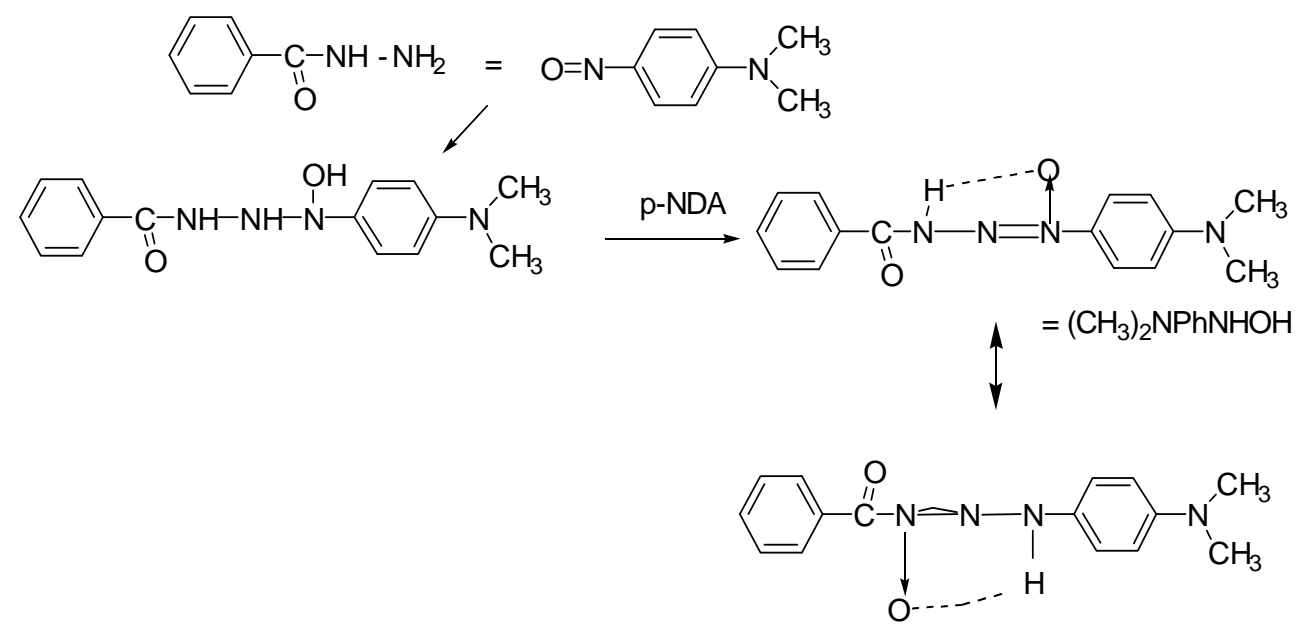

Method II
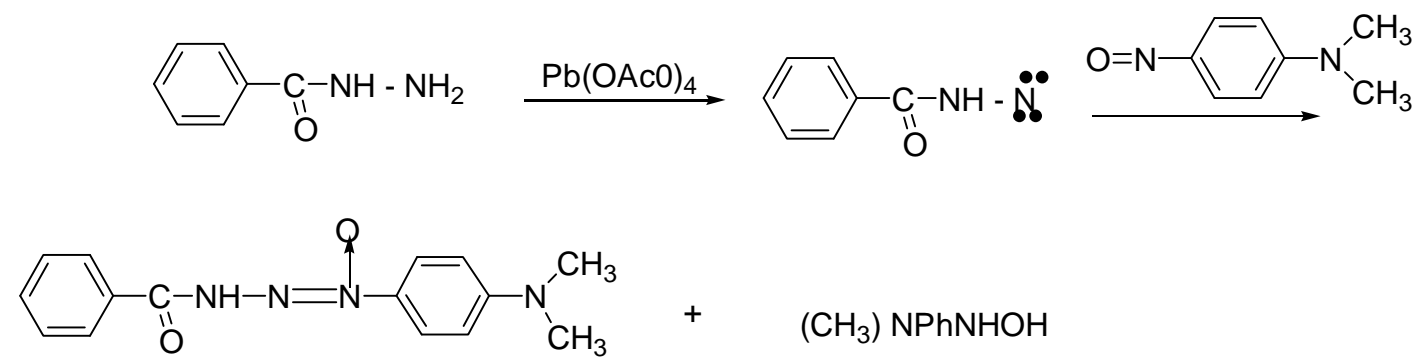

Table 1 shows the physical and spectral characteristics of the products.

The conditions for optimum yield for method I were $\mathrm{pH} 4-5$, temperature $50^{\circ} \mathrm{C}$; mole ratio 3:2 p-NDA : acyl hydrazine. For method II it was $\mathrm{pH} 5$, temperature $40^{\circ} \mathrm{C}$; mole ratio 3:2 p-NDA: acyl hydrazine. The products from methods I and II had the same melting point and spectral characteristics.
The triazene $-\mathrm{N}$ - oxides were found to be soluble in aqueous alkaline medium but insoluble in acidic medium. This may be due to abstraction of the $\mathrm{N}$ - oxygen by the base to form $\mathrm{H}_{2} \mathrm{O}$.

The para and meta substituted isomer were found to have higher yield than the ortho substituted isomers probably due to steric effect. 
Table 1: $\quad$ Physical and spectral characteristics of products

\begin{tabular}{|c|c|c|c|c|c|}
\hline S.N & Hydrazine & $\begin{array}{l}\text { Colour / } \\
\text { M.pt }\end{array}$ & $\begin{array}{l}\mathrm{UV} \lambda_{\max }\left(\mathrm{E}_{\max }\right) \\
(\mathrm{nm})\end{array}$ & IR $\mathrm{cm}^{-1}$ & $\begin{array}{l}\text { Yield } \\
\%\end{array}$ \\
\hline 1 & Benzoyl & $\begin{array}{l}\text { Black solid } \\
186-187\end{array}$ & $\begin{array}{l}480(2673) \\
400(5180) \\
353(11195) \\
280(6627)\end{array}$ & $\begin{array}{l}3280 \\
1600 \\
1530 \\
1265\end{array}$ & 80.8 \\
\hline 2 & o- methyl benzoyl & $\begin{array}{l}\text { Black solid } \\
198-199\end{array}$ & $\begin{array}{l}480(4470) \\
400(8609) \\
392(7285) \\
353(7847) \\
265(13411)\end{array}$ & $\begin{array}{l}3420 \\
1650 \\
1600 \\
1570 \\
1250\end{array}$ & 58 \\
\hline 3 & m- methyl benzoyl & $\begin{array}{l}\text { Black solid } \\
189-190\end{array}$ & $\begin{array}{l}476(1862) \\
340(29795) \\
300(10428) \\
270(12291) \\
220(3728)\end{array}$ & $\begin{array}{l}3250 \\
1660 \\
1600 \\
1280 \\
1250\end{array}$ & 88.7 \\
\hline 4 & p- chloro benzoyl & $\begin{array}{l}\text { Yellowish } \\
\text { brown solid } \\
212-213\end{array}$ & $\begin{array}{l}480(6369) \\
385(7166) \\
300(5308) \\
270(6900) \\
250(6369) \\
225(5838)\end{array}$ & $\begin{array}{l}3220 \\
1660 \\
1590 \\
1520 \\
1270\end{array}$ & 70.0 \\
\hline 5 & o- chloro benzoyl & $\begin{array}{l}\text { Brown } \\
190-191\end{array}$ & $\begin{array}{l}480(16631) \\
390(20170) \\
300(17693) \\
270(20878)\end{array}$ & $\begin{array}{l}3410 \\
1650 \\
1560 \\
1250\end{array}$ & 57.5 \\
\hline 6 & p-amino benzoyl & $\begin{array}{l}\text { Black } \\
224-225\end{array}$ & $\begin{array}{l}434(13155) \\
390(8970) \\
300(12159) \\
270(13554)\end{array}$ & $\begin{array}{l}3360 \\
1690 \\
1590 \\
1520 \\
1285\end{array}$ & 82.13 \\
\hline 7 & $\begin{array}{l}\text { Isonicotinic acid } \\
\text { hydrazide }\end{array}$ & $\begin{array}{l}\text { Black } \\
188-189\end{array}$ & $\begin{array}{l}473(18523) \\
430(22916) \\
400(22441) \\
352(26716) \\
270(35740) \\
235(36690)\end{array}$ & $\begin{array}{l}3320 \\
1665 \\
1600 \\
1520 \\
1270\end{array}$ & 36.5 \\
\hline 8 & Phenyl hydrazine & $\begin{array}{l}\text { Yellow } \\
\text { liquid }\end{array}$ & $\begin{array}{l}423(29,000) \\
273(5750)\end{array}$ & $\begin{array}{l}3430 \\
3240 \\
1600 \\
1510,1240\end{array}$ & \\
\hline 9 & $\begin{array}{l}\text { Para- nitroso, } \mathrm{N}, \mathrm{N}- \\
\text { dimethyl aniline }\end{array}$ & $\begin{array}{l}\text { Green solid } \\
84-85\end{array}$ & $\begin{array}{l}425(34,340) \\
275(22,827) \\
225(43,307)\end{array}$ & & \\
\hline
\end{tabular}


The strong IR bands in the region 1650 $1695 \mathrm{~cm}^{-1}$ indicate a conjugated carbonyl system. Bands between $3220-3430 \mathrm{~cm}^{-1}$ indicate $\mathrm{H}-$ bonded $\mathrm{N}-\mathrm{H}$ group while the bands at $1240-1290 \mathrm{~cm}^{-1}$ indicate the azoxy group $-\mathrm{N}=\mathrm{N}^{-}$.

UV $\lambda_{\max }$ at $370 \mathrm{~nm}$ seems characteristics of triazene $-\mathrm{N}$ - oxide when the acyl group is attached to $\mathrm{N}-1$ or $\mathrm{N}-3$. The UV spectrum of the triazene $-\mathrm{N}$ - Oxide of phenyl hydrazine (1, 3-diaryl) is similar to that of p-NDA (table 1, nos $7 \& 8$ ); with a slight bathochromic shift of the $\lambda_{\max }$ ( $423 \mathrm{~nm}$ to $425 \mathrm{~nm}, 273 \mathrm{~nm}$ to $275 \mathrm{~nm}$ ) with accompanying marked increase in $\mathrm{E}_{\max }$. In the triazene $-\mathrm{N}$-oxide from benzoyl, o- and m-methyl benzoyl, o- and pchlorobenzoyl, the $\lambda_{\max }$ at $423 \mathrm{~nm}$ was absent rather, there was a band between $476 \mathrm{~nm}$ to $480 \mathrm{~nm}$.

Mass spectra of the 3- benzoyl - 1- (4'$\mathrm{N}, \mathrm{N}$-dimethylaminophenyl) triazene $-\mathrm{N}$ oxide gave peaks supportive of the structure:

$284 \quad-\quad M^{+}$(very small)

164 - Due to breakage at bond $\alpha$ to the azo bond. $\left(\mathrm{C}_{6} \mathrm{H}_{5} \mathrm{CON}=\mathrm{N}-\mathrm{N}=\right.$ $\mathrm{OH}^{+}$)

$150-\left(\mathrm{CH}_{3}\right)_{2} \mathrm{~N}-\mathrm{C}_{6} \mathrm{H}_{4}-\mathrm{NO}$

120 - $\quad$ Due to breakage at bond $\alpha$ to the azo bond $\left(\mathrm{CH}_{3}\right)_{2} \mathrm{~N}-\mathrm{C}_{6} \mathrm{H}_{4}$

105 - base peak $\mathrm{C}_{6} \mathrm{H}_{5} \mathrm{C}=\mathrm{O}$ characteristic of carbonyl systems.

Degradation of the 3 - benzoyl - 1- (4'$\mathrm{N}, \mathrm{N}$-dimethylaminophenyl) triazene $-\mathrm{N}$ oxide gave pure benzoic acid also confirming the presence of the benzoyl function.

\section{CONCLUSION}

This work has shown that 3-acyl triazene $\mathrm{N}$ - oxide can be prepared by the Fisher and Wacker method (method 1) and by the Hoesch and Koppel method (method 1). The spectral analysis supports the assigned structure for the triazene - oxide.
It would be interesting to investigate the pharmacological properties of these triazene $-\mathrm{N}$ - oxides as Novocain, a derivative of p-aminobenzoic acid, is used in anesthetics.

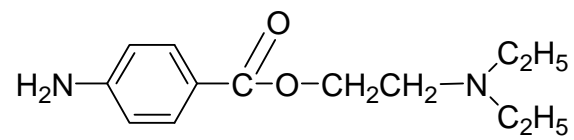

The replacement of the -O$\mathrm{CH}_{2} \mathrm{CH}_{2} \mathrm{~N}\left(\mathrm{CH}_{3}\right)_{2}$ by the triazene unit may give different pharmacological activity to the compound.

\section{ACKNOWLEDGEMENTS}

I wish to thank Dr Tempesta of Analytical Service Centre Atlanta, USA for providing the mass spectrum and the University of Benin for providing the research grant for this work.

\section{REFERENCES}

1 Smith, R.H., Denlinger, C.L., Kupper, S.R. and Michejda, C.J.; J. Am. Chem. Soc. 106 (1984) $1056-1059$.

2 Fisher, O. and Wacker,; L. Chem. Ber 22 (1889) 622.

3 Hoesch, L. and Koppel, B.; Helv. Chem Acta 64:3 (1981) 868.

4 Chatlangya, P.D., Bhander, C.S. and Songani, N.C.; J. Indian Chem. Soc. 54:10 (1977) 1001.

5 Miesel, J.L., (Lily H. Co editors); US Pub. Pat. Appl. B. (1976) 10 February.

6 Vogel, A.I.; A textbook of Practical Organic Chemistry $4^{\text {th }}$ Edn. p 345, 677 Longman Group Ltd, London 1976.

7 Chaco, M.C. and Lyer, B.H.; J. Org. Chem. 25(1960) 186.

8 Nakanishi, K.; IR Absorption Spectroscopy. p 51 Holden day, San Francisco and Nankado Company Tokyo 1962. 
Received: 12/5/06

Accepted: 12/5/06 
